\title{
THE ACCEPTANCE OF MOOC AMONG TVET STUDENTS IN HIGHER EDUCATION: AN OBSERVATION
}

\author{
Mohd Erfy Ismail1), Norhasyimah Hamzah'2), Arihasnida Ariffin ${ }^{3)}$, Irwan Mahazir Ismail(4), Khairul \\ Azhar Mat Daud ${ }^{5)}$, Pipit Utami6), Moh. Khairudin ${ }^{7)}$ \\ ${ }^{1}$ Faculty of Technical \& Vocational Education, Universiti Tun Hussein Onn Malaysia \\ email: erfy@uthm.edu.my \\ ${ }^{2}$ Faculty of Technical \& Vocational Education, Universiti Tun Hussein Onn Malaysia \\ email: hasyimah@uthm.edu.my \\ ${ }^{3}$ Faculty of Technical \& Vocational Education, Universiti Tun Hussein Onn Malaysia \\ email: hasnida@uthm.edu.my \\ ${ }^{4}$ Faculty of Technical \& Vocational Education, Universiti Tun Hussein Onn Malaysia \\ email: irwanm@uthm.edu.my \\ ${ }^{5}$ Faculty of Technology Creative \& Heritage, Universiti Malaysia Kelantan \\ email: azhar.md@umk.edu.my \\ ${ }^{6}$ Faculty of Engineering, Universitas Negeri Yogyakarta \\ email: pipitutami@uny.ac.id \\ ${ }^{7}$ Faculty of Engineering, Universitas Negeri Yogyakarta \\ email:moh_khairudin@uny.ac.id
}

\begin{abstract}
Teaching traditionally through the use of textbooks and lecture makes the decline in learning desirability among technical \& vocational education and training (TVET) students. In the $21^{\text {st }}$ century learning, the technology changes in learning such as e-learning have led to the use of technology in the field of TVET. Most TVET educators have started using the Massive Open Online Course (MOOC) as a learning medium. The purpose of this study to enhance the quality of teaching and learning for TVET students in higher education. Teaching and learning in TVET lack of using blended learning approach. This study examine students' acceptance and specify the criteria that make Massive Open Online Courses (MOOC) suitable for TVET in learning environment. The respondent are 60 students randomly selected from Creativity and Innovation courses. This study employed the quantitative methodology which include the use of questionnaire with Likert scale. The questionnaire consist four construct to examine the criteria of MOOC for teaching and learning in TVET. The reliability test of Cronbach Alpha is 0.813 . Data were analyzed using descriptive analysis. The findings show that the constructs of perceived of usefulness (mean=1.85), perceived ease of use (mean=1.90), user attitude toward use (mean=1.86) and actual system use (mean=1.83) towards the acceptance of MOOC in teaching and learning among TVET students. In general, these finding also showed positive respond to implement MOOC for TVET in higher education. Thus, in making the learning process more interesting, the educators should improving existing teaching style.
\end{abstract}

Keywords : MOOC, Students' Acceptance, TVET, Teaching \& Learning 


\section{INTRODUCTION}

Information and Communication Technologies (ICT) progress is bringing many changes in education 21st century. The most significant change now is an increase in the ratio of knowledge that can be shared (sharable) and transparency (openness) in which the sources of this knowledge can be accessed free of charge by the global community. Content, materials science and academic resources available on the Internet that can be accessed free of charge for all levels and all walks of life. ICT have gained substantial attention during the last decade and are regarded as important element in the 21st century for education field (Sindu \& Santyadiputra, 2017; Tondeur et. al., 2017). Technical and Vocational Education Training (TVET) is one of the most important field of education because they produce a workforce are skilled and knowledgeable. According to Omar, Rashid \& Puad (2018), TVET plays role to produce workers with reflexes that allow them to interact with job duties in the organization of workplace.

\section{Technical and Vocational Education Training (TVET) in Higher Education}

In order to produce skilled, flexible, and easily trained manpower, trainees or students must be able to adapt to technological change (Griffin, Care, \& McGaw, 2012). Not only students but also trainers and teachers should be encouraged to vary their educational approaches and to avoid limiting their practice to only traditional methods of instruction. Actually, technology can improve motivation (Jones, McDermott, Tyrer \& Zanker, 2018), but even more importantly, it can affect the delivery of learning; delivery methods must be effective if they are to improve the problem solving process (Sandi-Urena, Cooper \& Stevens, 2012; Pebriyawan, Darmawiguna, \& Sindu, 2017).

TVET is one of the education field in higher education that is being given a priority nowadays. TVET is a field that focuses on skill that is psychomotor domain, albeit cognitive domain and affective domain are not discarded and still plays a very important element in their training. Is TVET (or engineering based) students have same learning attitude or require same pedagogical approach in comparison to normal (non-engineering based) students? TVET student usually have good ability in 'learning by doing' (Mahazir, Norazah, Rosseni, Arif \& Ridzwan, 2015). Learning by doing term shows that TVET students have a greater potential in skill. Besides that, technology advancement in Teaching and Learning (T\&L) process could be use as a catalyst of innovative workforce. Moreover, researchers like Kusumantara, Santyadiputra \& Sugihartini, 2017 and McCutcheon, Lohan, Traynor \& Martin (2015) reveals conventional teaching method will limit students learning outcome and educators will find embarrassment in providing students better quality of learning experience.

TVET student must shift from the traditional method of teacher centered learning to one of student centered learning in order to provide a successful experience for all learners (Duffy \& Bowe, 2010). ICT is a medium that can be used to improve the process of interaction for and between students, as it has revolutionized learning environments throughout the world (Omar et al., 2018). Therefore, it is crucial that MOOC be implemented in order to ensure that the quality of teaching and learning will benefit students; at the same time, this implementation will contribute to the development of diverse, alternative methods for improving student performance in Technical and Vocational Education Training (TVET) in Malaysia. 


\section{Massive Open Online Courses (MOOC)}

Massive Open Online Courses (MOOC) are one of the most prominent trends in higher education in recent years.

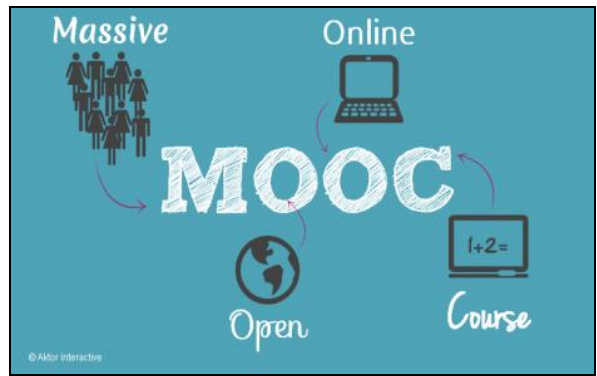

Figure 1. Elements of MOOC (Source: Aktor Interactive)

The term 'MOOC' represents open access, global, free, video based instructional content, videos, problem sets and forums released through an online platform to high volume participants aiming to take a course or to be educated (Baturay, 2015). MOOC has a global reach, participation is not limited, and open access via the internet through a combination of social networking and video podcasts to attract students of different ages, races, backgrounds, abilities, interests, and others (Brahimi \& Sarirete, 2015). MOOC phenomenon has been the subject of debate that is often spoken in the field of education especially in higher education.

\section{Technology Acceptance Model (TAM)}

There are many theoretical perspectives have been developed in order to understand how end users make decisions to use technology applications. Theories provide tools to understand success or failure in implementation processes of new IT applications. The most dominant theories in IT research are Innovation Diffusion Theory (IDT) (Rogers, 1995), Theory of Planned Behavior (TPB) (Fishbein \& Ajzen, 1975), the Unified Theory of Acceptance and Use of Technology (UTAUT) (Venkatesh et al.,
2012), the FITT framework (Ammenwerth, Iller and Mahler, 2006) and the Technology Acceptance Model (TAM) (Davis 1989). Technology Acceptance Model (TAM) (Davis, 1989) is possibly the most frequently used among all other theories (Yarbrough \& Smith, 2007).

TAM theory is based on principles adopted from Fishbein and Ajzen (1975) attitude paradigm from psychology, which specifies how to measure the behaviour components of attitudes, distinguishes between beliefs and attitudes and specifies how external stimuli are causally linked to beliefs, attitudes and behavior. The theoretical model on which TAM is based is the Theory of Reasoned Action (TRA). TRA is a general model which is concerned with individuals. According to TRA an individual determined by the individual norms concerning the behavior in question. In addition an individual existing behavior (Ajzen \& Fishbein, 1980). The Technology Acceptance Model (TAM) determines the user acceptance of any technology perceived usefulness (PU) and perceived ease of use (EU) factors. PU defines as the degree to which an individual believes that using a particular system will enhance the task performance. EU defines as the degree to which an individual believes that using a particular system is free of physical and mental effort (Davis, 1989). The TAM suggests that intention to accept technology is determined directly by attitude, perceived usefulness and perceived ease of use. According to TAM individuals' intention to use technology determines the actual use of the application and attitudes toward technology affect the intention (Davis et al., 1989; Davis \& Venkatesh, 2004; Venkatesh et al., 2012). 


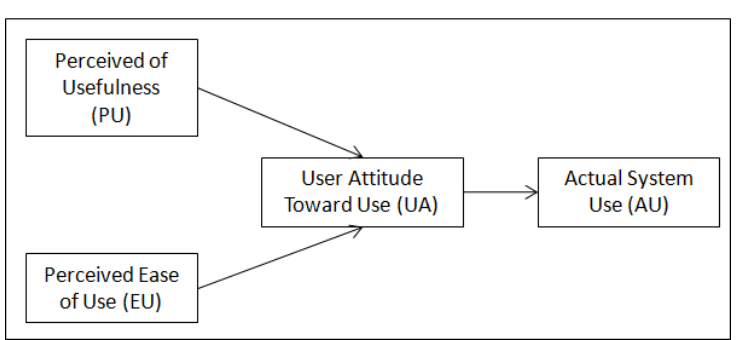

Figure 1. Technology Acceptance Model

(Davis et al., 1989)

\section{Research Question and Aims}

This study aimed to investigating the acceptance of MOOC in TVET institution based on the students' knowledge and experience with MOOC. To achieve this purpose of the study, the researchers sought to answer the following question:

What are the acceptance of MOOC in TVET Higher Education, Malaysia? Using TAM model focus on this construct:

i. Perceived of Usefulness (PU);

ii. Perceived Ease of Use (EU);

iii. User Attitude Toward Use (UA);

iv. Actual System Use (AU).

\section{Research Terms}

Massive open Online Course (MOOC) is a tool for blended learning and flipped learning for student use through ICT device such as the use of handheld (mobile) devices or personal digital assistants (PDAs), cell phones, laptops and any other handheld information technology device that may be used in Teaching and Learning. The construct that represents an individual's like or dislike for an item that focus the acceptance of MOOC among TVET's student in Higher Education (Figure 2).

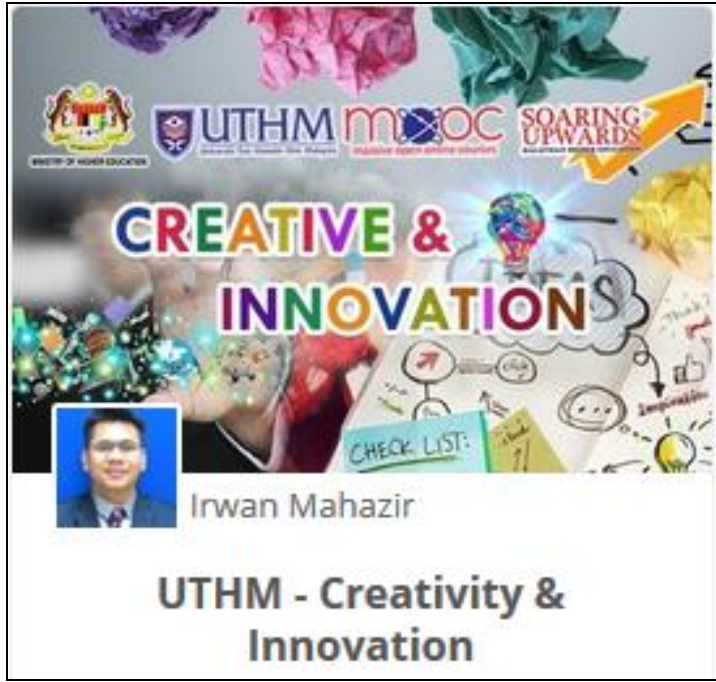

Figure 2. MOOC for Creativity and Innovation Course

\section{Research Limitations}

The research focuses on students in the Faculty of Technical and Vocational at the Universiti Tun Hussein Onn, Malaysia, regardless of their acceptance of MOOC.

\section{METHODOLOGY}

Methodology is the process by which historians gather evidence and formulate ideas about the past. It is a framework through which account of the past is constructed (Reisigl, 2015). The purposes of this study to examine students' acceptance and specify the criteria that make Massive Open Online Courses (MOOC) suitable for TVET in learning environment. Meanwhile, the participants, instrument and analysis data were discuss.

This study consisted 240 students from Creativity and Innovation course in the Faculty of Technical and Vocational at the Universiti Tun Hussein Onn, Malaysia. However,the researchers distributed the study instrument (survey questionnaire) to 60 students who were randomly selected from the course as the sample for this study.

$$
\text { A survey questionnaire }
$$

developed by the researchers was utilized to collect data in order to investigate students' acceptance on 
MOOC. The instrument consisted of 20 statements in online questionnaires to meet its purpose. A five point Likert scale was used $(5=$ strongly agree $1=$ strongly disagree) and was completed by the participants. A correlation coefficient value (0.86), calculated on Alpha Cronbach, was used to test the internal reliability of the questionnaire and it showed an acceptable reliability value. Descriptive and analytical statistics as well as the Statistical Package for the Social Sciences (SPSS) were used to show the acceptance of MOOC among TVET's student.

\section{RESULTS AND DISCUSSION}

The student as participants responded to the constructs of perceived of usefulness (PU), perceived ease of use (EU), user attitude toward use (UA) and actual system use (AU) towards MOOC through online survey (Figure 3). Mean and standard deviation scores were calculated for each the following four construct which are perceived of usefulness, perceived ease of use, user attitude toward use and actual system use. Descriptive as well as the Statistical Package for the Social Sciences (SPSS) were used.

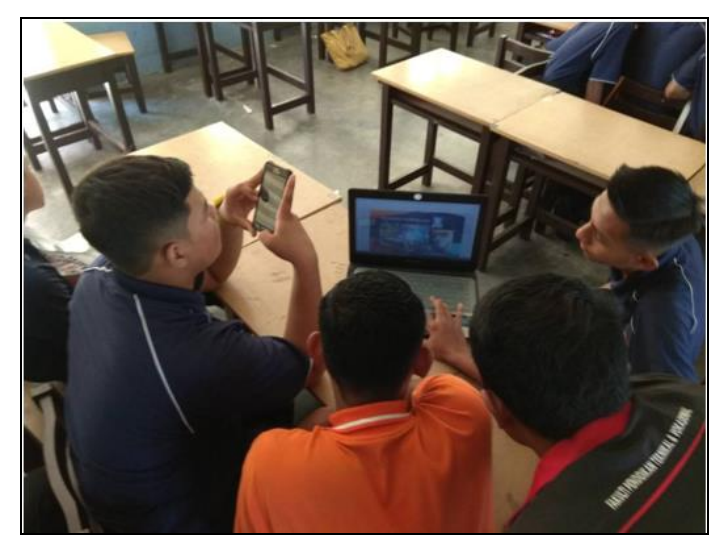

Figure 3. The use of MOOC by respondents

\section{Perceived of Usefulness}

Table 1 shows descriptive statistic for the first construct. Perceived of usefulness is defined the degree to believe that TVET in higher education will be improving by using MOOC. The measurement of perceived of usefulness comprises of five items modified to the context of this study.

The result for construct perceived of usefulness show that the highest mean is PU4 (mean=1.90). Students strongly agree MOOC will save the time of teaching and learning in higher education. Meanwhile the lowest mean on item PU2, MOOC allows to access information outside of classroom (mean=1.67). Alraimi, Zo, and Ciganek (2015) reported that the intention to continue using MOOCs was significantly influenced by the courses' perceived reputation, perceived openness, perceived usefulness and overall user attitude toward use with perceived reputation and perceived openness being the strongest predictors. Therefore, TVET students' give positive feedback for using MOOC in Teaching and Learning process.

Table 1. Perceived of Usefulness

\begin{tabular}{clcc}
\hline Num. & \multicolumn{1}{c}{ Measured Item } & Mean & $\begin{array}{c}\text { Std. } \\
\text { Dev. } \\
(\boldsymbol{\sigma})\end{array}$ \\
\hline PU1 & $\begin{array}{l}\text { MOOC will enable to } \\
\text { get the information of } \\
\text { the learning content } \\
\text { quickly } \\
\text { MOOC allows to }\end{array}$ & 1.88 & 1.08 \\
PU2 & $\begin{array}{l}\text { Macess information } \\
\text { outside of classroom } \\
\text { MOOC is useful in } \\
\text { PU3 }\end{array}$ & 1.67 & 1.04 \\
& $\begin{array}{l}\text { information from } \\
\text { lecturer } \\
\text { MOOC will save the } \\
\text { time of teaching and } \\
\text { learning } \\
\text { Using MOOC would } \\
\text { improve learning } \\
\text { performance }\end{array}$ & 1.9 & 1.04 \\
\hline PU5 & 1.9 & 0.99 \\
\hline
\end{tabular}




\section{Perceived Ease of Use}

Table 2 shows descriptive statistic for the second construct. Perceived of ease of use is defined the degree to which believe that using Massive open Online Course (MOOC) in order to improve the quality of TVET in higher education. The measurement of perceived of ease of use contained of five items modified to the context of this study.

The result for construct perceived of ease of use show that the highest mean is EU1,'Learning to operate MOOC would be easy for me' (mean=1.97). Besides, the lowest mean is 1.82 on item EU5 'It would be easy for me to become skillful at using MOOC'. MOOCs have emerged as educational tools that can meet the learners' needs and interests (Wise, Cui, Jin, \& Vytasek, 2017). Overall, students' response that MOOC will make them easy and flexible to use.

Table 2. Perceived Ease of Use

\begin{tabular}{clcc}
\hline Num. & \multicolumn{1}{c}{ Measured Item } & Mean & $\begin{array}{c}\text { Std. } \\
\text { Dev. } \\
(\boldsymbol{\sigma})\end{array}$ \\
\hline EU1 $\quad \begin{array}{l}\text { Learning to operate } \\
\text { MOOC would be easy } \\
\text { for me }\end{array}$ & 1.97 & 1.03 \\
EU2 & $\begin{array}{l}\text { I would find it easy get } \\
\text { MOOC to do what I } \\
\text { need to do }\end{array}$ & 1.92 & 0.94 \\
EU3 & $\begin{array}{l}\text { My interaction with } \\
\text { MOOC would be clear } \\
\text { and understandable }\end{array}$ & 1.93 & 1.01 \\
& $\begin{array}{l}\text { I would find MOOC to } \\
\text { be flexible to interact } \\
\text { with }\end{array}$ & 1.87 & 1.00 \\
EU4 & $\begin{array}{l}\text { It would be easy for } \\
\text { me to become skillful } \\
\text { while using MOOC }\end{array}$ & 1.82 & 0.97 \\
\hline EU5
\end{tabular}

\section{User Attitude Toward Use}

The result in table 3 shows descriptive statistic for the third construct which is user attitude toward use. It refers to the degree of experienced in a variety of situations and connected to MOOC. It is a highly personal assessment that is greatly affected by user expectations. The measurement of user attitude toward use construct contained five items and modified to the context of this study.

The result for construct perceived of usefulness show that the highest mean is US1 (mean=1.93). Students completely satisfied when they using MOOC in TVET. Meanwhile the lowest mean on item US2, student feel very confident in using the MOOC (mean=1.77). Frank (2012) and Levy (2011) reported students being satisfied with the high degree of participation (e.g., posting of thoughts, questions, and useful website links) found in the online discussion boards or chat rooms as these activities helped them in their learning. Nowadays, students' satisfaction in using MOOC for TVET in higher education can be received positively.

\section{Table 3. User Attitude Toward Use}

\begin{tabular}{|c|c|c|c|}
\hline Num. & Measured Item & Mean & $\begin{array}{l}\text { Std. } \\
\text { Dev. } \\
(\sigma)\end{array}$ \\
\hline US1 & $\begin{array}{l}\text { I completely satisfied } \\
\text { in using the MOOC }\end{array}$ & 1.93 & 1.02 \\
\hline US2 & $\begin{array}{l}\text { I feel very confident in } \\
\text { using the MOOC }\end{array}$ & 1.77 & 0.95 \\
\hline US3 & $\begin{array}{l}\text { I found it easy to } \\
\text { share information } \\
\text { using MOOC }\end{array}$ & 1.83 & 1.00 \\
\hline US4 & $\begin{array}{l}\text { I can accomplish the } \\
\text { task quickly using this } \\
\text { procedure }\end{array}$ & 1.88 & 0.98 \\
\hline US5 & $\begin{array}{l}\text { I believe that from } \\
\text { using MOOC will } \\
\text { increase the learning } \\
\text { quality }\end{array}$ & 1.92 & 1.00 \\
\hline
\end{tabular}

\section{Actual System Use}

Table 4 shows descriptive statistic for the Actual System Use construct. Actual System Use refer to attempts 
bridge the gap between human's goals and the MOOC. This is being done by introducing the students with interactive MOOC and observe their performance in TVET. The measurement of actual system use comprises of five items modified to the context of this study.

The result for construct perceived of usefulness show that the highest mean is AU2 (mean=1.93). Students strongly agree the procedure through MOOC on learning content. Meanwhile the lowest mean on item AU5, student think that they would like to use this MOOC (mean=1.75). Attitude toward MOOC would have a positive effect on the intention to continue using them (Dewi, Dantes, \& Indrawan, 2018; Zhou, 2016). Usability of MOOC in TVET is proven through a very promising student's admission.

Table 4. Actual System Use

\begin{tabular}{|c|c|c|c|}
\hline Num. & Measured Item & Mean & $\begin{array}{l}\text { Std. } \\
\text { Dev. } \\
(\sigma)\end{array}$ \\
\hline AU1 & $\begin{array}{l}\text { It easy to interact } \\
\text { with MOOC }\end{array}$ & 1.78 & 1.00 \\
\hline AU2 & $\begin{array}{l}\text { The procedure } \\
\text { through MOOC on } \\
\text { learning content }\end{array}$ & 1.93 & 0.97 \\
\hline AU3 & $\begin{array}{l}\text { I found it easy to } \\
\text { decide which the } \\
\text { case need to be } \\
\text { I found the various }\end{array}$ & 1.87 & 0.97 \\
\hline AU4 & $\begin{array}{l}\text { functions in this } \\
\text { MOOC } \\
\text { were well integrate } \\
\text { I think that I would }\end{array}$ & 1.85 & 0.94 \\
\hline AU5 & $\begin{array}{l}\text { like to use this } \\
\text { MOOC }\end{array}$ & 1.75 & 0.90 \\
\hline
\end{tabular}

\section{Future Work}

Designing a Technology

Acceptance Model for MOOC is simply a first step in systems development. Looking ahead, for evaluating MOOC in TVET learning quality in TVET institution using this questionnaire design.

\section{CONCLUSION}

In fact, with increasing and emphasizing on improving the quality of teaching and learning in TVET institution. We created new needs to help and make better choices as using MOOC as a tool for learning. Therefore there is an eminent need to investigate the current position of the acceptance of those mobile health applications that are tailored towards the tracking patients' condition, share patients information and access. We proposed methodology designed a Technology Acceptance Model (TAM) approach based on the literature studies aimed to evaluate and investigate usability test for Perceived of Usefulness, Perceived Ease of Use, User Attitude Toward Use and Actual System Use as important for the user evaluation in the MOOC to assess if such this system will be of much use to the intended users.

\section{ACKNOWLEDGMENTS}

This research was fully supported by Short Term Grant (U646) from Research Management Center (RMC), Universiti Tun Hussein Onn Malaysia. We thank our colleagues from Universiti Malaysia Kelantan and Universitas Negeri Yogyakarta who provided insight and expertise that greatly assisted the research, although they may not agree with all of the interpretations of this paper. We would also like to thank JPTK's editorial team and "anonymous" reviewers for their efforts in the process of publication. We are also immensely grateful to reviewers for their comments on an earlier version of the manuscript, although any errors are our own and should not tarnish the reputations of these esteemed persons. 


\section{REFERENCES}

Alraimi, K. M., Zo, H., \& Ciganek, A. P. (2015). Understanding the MOOCs continuance: the role of openness and reputation. Computers \& Education, 80, 28-38

Dewi, S. P., Dantes, G. R., \& Indrawan, G. (2018). Evaluasi Usability Pada Aspek Satisfaction Menggunakan Teknik Kuesioner Pada Sistem LMS Program Keahlian Ganda. Jurnal Pendidikan Teknologi dan Kejuruan, 15(1).

Duffy, G. \& Bowe, B. (2010). A framework to develop lifelong learning and transferable skills in an engineering programme. Paper presented at the 3rd International Symposium for Engineering Education, 2010, University College Cork, Ireland.

Frank, S. J. (2012). MITx's online circuit and analysis course [Education]. IEEE Spectrum, 49(9).

Griffin, P., Care, E., \& McGaw, B. (2012). The changing role of education and schools. In Assessment and teaching of 21st century skills (pp. 1-15). Springer, Dordrecht.

Jones, L. C., McDermott, H. J., Tyrer, J. R., \& Zanker, N. P. (2018). Future engineers: the intrinsic technology motivation of secondary school pupils. European Journal of Engineering Education, 43(4), 606619.

Kusumantara, K. S., Santyadiputra, G. S., \& Sugihartini, N. (2017). Pengaruh E-Learning Schoology Terhadap Hasil Belajar Simulasi Digital Dengan Model Pembelajaran Savi. Jurnal Pendidikan Teknologi dan Kejuruan, 14(2).

Levy, D. (2011). Lessons learned from participating in a connectivist massive online open course (MOOC). In Proceedings of the Chais conference on instructional technologies research 2011: Learning in the technological era (pp. 31-36).

Mahazir, I. I., Norazah, M. N., Rosseni, D., Arif, A. A., \& Ridzwan, C. R. (2015). Design and development performance-based into mobile learning for TVET. Procedia-Social and Behavioral Sciences, 174, 1764-1770.

McCutcheon, K., Lohan, M., Traynor, M., \& Martin, D. (2015). A systematic review evaluating the impact of online or blended learning vs. face-to-face learning of clinical skills in undergraduate nurse education. Journal of advanced nursing, 71(2), 255-270.

Omar, M. K., Rashid, A. M., \& Puad, M. H. M. (2018). Examining job satisfaction factors toward retaining Malaysian TVET instructors in the teaching profession. International Journal of Engineering \& Technology, 7(2.10), 44-49.

Pebriyawan, I. D., Darmawiguna, I. G M., \& Sindu, I. G. P. (2017). Pengembangan E-Modul Pada Mata Pelajaran Pemrograman Web Dinamis Kelas Xi Dengan Model Problem Based Learning Di Smk Negeri 2 Tabanan. Jurnal Pendidikan Teknologi dan Kejuruan, 14(1).

Reisigl, M. (2017). The discoursehistorical approach. In The Routledge Handbook of Critical Discourse Studies (pp. 44-59). Routledge.

Sandi-Urena, S., Cooper, M., \& Stevens, R. (2012). Effect of cooperative problem-based lab instruction on metacognition and problem-solving skills. Journal of Chemical 
Education, 89(6), 700-706.

Sindu, I. G. P., \& Santyadiputra, G. S. (2017). Pengembangan Web Service Profil Jurusan Dan Fakultas (Studi Kasus Fakultas Teknik Dan Kejuruan Undiksha). Jurnal Pendidikan Teknologi dan Kejuruan, 14(1).

Tondeur, J., Aesaert, K., Pynoo, B., Braak, J., Fraeyman, N., \& Erstad, O. (2017). Developing a validated instrument to measure preservice teachers' ICT competencies: Meeting the demands of the 21st century. British Journal of Educational Technology, 48(2), 462-472.

Wise, A. F., Cui, Y., Jin, W., \& Vytasek, J. (2017). Mining for gold: Identifying content-related MOOC discussion threads across domains through linguistic modeling. The Internet and Higher Education, 32, 11-28.

Zhou, M. (2016). Chinese university students' acceptance of MOOCs: A self determination perspective. Computers \& Education, 92-93, 194-203.

Baturay, M. H. (2015). An overview of the world of MOOCs. ProcediaSocial and Behavioral Sciences, 174, 427-433.

Brahimi, T., \& Sarirete, A. (2015). Learning outside the classroom through MOOCs. Computers in Human Behavior, 51, 604-609.

Rogers, E.M. (1995), Diffusion of Innovations, 4th ed., The Free Press, New York, NY.

Fishbein, M., \& Ajzen, I. (1975). Belief, attitude, intention and behavior: An introduction to theory and research.

Venkatesh, V., Thong, J. Y., \& Xu, X. (2012). Consumer acceptance and use of information technology: extending the unified theory of acceptance and use of technology. MIS quarterly, 157-178.
Ammenwerth, E., Iller, C., \& Mahler, C. (2006). IT-adoption and the interaction of task, technology and individuals: a fit framework and a case study. BMC medical informatics and decision making, $6(1), 3$.

Davis, F. D. (1989). Perceived usefulness, perceived ease of use, and user acceptance of information technology. MIS quarterly, 319340.

Yarbrough, A. K., \& Smith, T. B. (2007). Technology acceptance among physicians: a new take on TAM. Medical Care Research and Review, 64(6), 650-672.

Ajzen, I., \& Fishbein, M. (1980). Understanding attitudes and predicting social behaviour.

Davis, F. D., \& Venkatesh, V. (2004). Toward preprototype user acceptance testing of new information systems: implications for software project management. IEEE Transactions on Engineering management, 51(1), 31-46.

Venkatesh, V., Thong, J. Y., \& Xu, X. (2012). Consumer acceptance and use of information technology: extending the unified theory of acceptance and use of technology. MIS quarterly, 157-178. 